\title{
Design Failure Affecting Maintenance Management on Public Higher Education Institution in Malaysia
}

\author{
Nuzaihan Aras Agus Salim ${ }^{1, a}$, Naziah Muhamad Salleh ${ }^{1}$ and Nurul Fadzila Zahari ${ }^{2}$ \\ ${ }^{1}$ School of Housing, Building and Planning, Universiti Sains Malaysia, 11800 Penang, Malaysia \\ ${ }^{2}$ Faculty of Architecture, Planning and Surveying, Universiti Teknologi MARA Perak, 32610 Seri Iskandar, Perak, Malaysia
}

\begin{abstract}
The issue of government building defect is keeping on reporting in the media and arising since 2007. These issues of building defects, maintenance and management have existing and it is deliberated up to the parliament level. The government keep continue increased the maintenance allowance in National Budgetary in every year. However, the building disasters and failures keep going develop their number of cases in Malaysia. Most of the issues are related with a weak maintenance management and faulty in design. This reflects to a poorly building condition, create discomfort and danger environment to the building users. Besides, it will result to a low quality building condition and reflect to a weak building maintenance management. Building defects arise through inappropriate or poor design, specification, construction and it will give an impact to maintenance management itself [1]. Errors in the design of the building are being debated and becoming a reason of major factor in building defect reproduction [2]. Thus, this issue will discover the major cause in building design failure that develop the building defects and verify the impact of design defects towards building maintenance management. The study involved with the public higher education institution in Malaysia focusing on main campuses and the distribution of questionnaire to the facility and maintenance management department. This research is aimed to produce a better understanding on the impact of building design failure towards the institution facilities' condition.
\end{abstract}

\section{Introduction}

In this era of the transformation of manufacturing technology and transportation system, it does lead to a different lifestyle and work style that resulted to the development of better infrastructure beside of old buildings in the city began to fall behind due to its outdated functionality and requirements [3]. Maintenance is the core agenda in preserving the building and the survival of this property. On the other hand, a complicated development process does bring into an inconvenience procedures to the designers and developers. This process involved with various phases of development, the provision of law, the development cost and expertise that are required a proper maintenance in future. The main problems in maintenance such as inadequate financial, bad management, and poor building design and detailing are usually raised by the maintenance management teams [4].

The relationship between maintenance and building design is closely to avoid any harmful during construction stage or during the building is occupied. It has been aligned in four sectors to avoid the need for unplanned maintenance at the post-occupation stage [5]. The four sectors is ruled into:

1. The main fabric which includes walls, floors, roofs, doors and windows;

2. Internal finishes which includes ceiling and wall finishes as well as floors;

3. Special design features such as decorative elements for the doors, windows, glass, air vents and special brick and stone work;

4. The fourth and the last sector is cleaning and housekeeping of all building components.

In addition, maintenance team shall be monitored during the design stage to find the solution under such condition is usually total replacement of the building's cladding [6]. A study has been carried out to find the critical parts in design that seldom brings a complicated maintenance issues such as poor material selection, a poor ventilation flow, a poor design on wet area, floor design weakness and ignorance of life span of materials and elements of the buildings do result to an expensive defects in their buildings [7].

Public Higher Education Institution in Malaysia takes a serious action to ensure all the facilities in a proper and safety condition. These institutions' facilities are control by facilities and maintenance department. Most of the maintenance work and operation is based on contingency and ad-hoc planning. However, the management of cleaning, building services contracts and landscaping are run by the outsource contractors through tendering process [8]. Therefore, this paper is to review the impact of building design failures to the Public Higher Education

\footnotetext{
${ }^{1}$ Corresponding author: nuzaihanaras@usm.my
} 
Institution in Malaysia that affecting the maintenance management perspectives.

\section{Literature Review}

Building failure occurs when the building loses its ability to perform its intended (design) function. Hence, building failures can be categorized into the two broad groups of physical (structural) failures (which result in the loss of certain characteristics, e.g., strength) and performance failures (which means a reduction in function below an established acceptable limit) [9]. These failures create a certain symptoms called defects onto physical building appearance [10].

Building defect is a failure or mistake that reduces the value of the building and may cause a dangerous condition to building user's if neglected. A defect may arise from some carious factors such as poor workmanship, design fault, wrong selection of material and so on. Building defects will result in various implications [11]. It may reflect the negligence occurred, and also illustrates the lack of concern on problems arising from the construction work on the building as well building refurbishment. A defect may be considered to be failing or unsatisfactory in the functional performance, user or statutory requirements of a building and might manifest itself within the fabric, structure, services and facilities of the affected to the building [12]. Ransom states that despite calls for closer integration of design and construction, the role remains essentially separate [13]. Figure 2.0 below revealed that over $90 \%$ of building defect could be explained partly or wholly as the result of readily identifiable faults in design and construction that could have been foreseen and hence prevented.

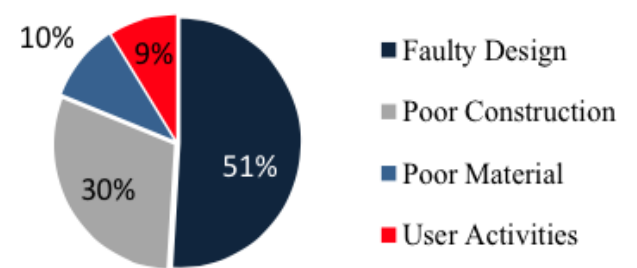

Figure 2.0: Causes of building defects according to Ransom (1981)

Singapore has produced ISO 9000 to improve the maintenance and reducing building defects. Technical, Human Resource and Management organizations found that the failures involve with defective materials, lack of training and skills, poor communication, etc. The strategy is founded to during planning stage that starting from design stage and selection in specification of materials to avoid any failures in the future [14].

\section{Faulty in Design}

Faulty design contributed to the number of building defects. Nonetheless, this is not a represent a poor performance of the building designers. The failure in design at the early stage would lead to deficiencies in the next stage after construction. Error in design is not only compromising the building environment, but also affected the building users [15]. Uncomfortable conditions in the building such as noise, inadequate lighting, uncomfortable temperature, high humidity and other physiological sectors may cause lower job satisfaction and increase in building related illness (BRI) symptoms [16].

Faulty design can occur due to an increase of maintenance cost. Some maintenance problems arise where the design is low probability of achievement in practice though it was satisfactory in principle. The good design achievement in the planning of buildings as worthy objects is understood and recognize, despite less understood and appreciated is the need for continuous maintenance [17]. Here are some causes of design failure towards maintenance:

a) Poor detailing and jointing

b) Insufficient thickness of concrete cover

c) Insufficient jointing between finishes faces

d) Incorrect locating conduits and piping at critical structure location

e) Insufficient length of owning

f) Insufficient provision for thermal movement

g) Insufficient structural design

h) Ignore maintenance access when designing

i) Not concerned on aggressive environment and weather condition effect

j) Less consideration the availability of maintenance tool during designing a building

k) Not relating exterior construction material selection to weather and climatic condition

\section{1 Poor Detailing and Jointing}

The detailing in architectural drawing performed at relatively large scale, of a part of a building, machine, or element, with dimensions or other information for use in construction. It represented the design, materials, size and installation work for a certain element in a building. The important of this large scale drawing is to emphasize the complicated elements that impossible to highlight in a floor plan. The drawing is clearly drawn and explained through the specification and shall be read and understand by the contractors to avoid any miscommunication during the construction stage.

The poor detailing shall contribute to poor installation, less of materials' quality and poor jointing. This may lead to a low quality of construction and reflected to a poor image of the contractor. However, the weakness of this faulty is caused by the architect who designing the detailing.

\subsection{Insufficient Thickness of Concrete Cover}

The description [22] of concrete cover to reinforcement is the last distance measured from the surface of the concrete member to the surface of the embedded 
reinforcing steel. This element functioned as a protection of the harden concrete located in the middle of the structure elements. Insufficient thickness of the concrete cover could bring harmful to the center and reduce the strength of the structure [23].

In addition, this mixture is the finishes of the structure and exposed to the weather or any chemical reaction that could contributes to Alkali-Silica reaction, Chloride Attack, Carbonation Attack, Sulphate Attack and detachment [11].

\subsection{Insufficient Jointing Between Finishes Faces}

Finishes is the last solution to prevent the internal structure from defects agent. The functionality react as the protection to the element. Therefore, some of the finishes created with waterproof properties, self-cleaning, ant-fungi, and others to avoid from the defects.

Some of the manufacturing create it in small panels such as floor tiles, wall tiles, roof tiles, tempered glass, soft-board and ceiling panels. Insufficient jointing between the panels will allow water penetration that creates water absorption [11]. This problem developed dampness on the surface of the finishes and produced mold growth in a certain progress of defects. This will contributes to a serious defects in the future [24].

\subsection{Incorrect Locating Conduits and Piping at Critical Structure Location}

The era of 80's building design installed the servicing piping and wiring in the building walls. It was believed to treat a good finishing to these services and kept from untidy appearance.

However, this result to difficulty in maintenance when the building achieves 40 years and above. Leaking of pipes causes to water absorption to the structure of the building and may produce dampness on surrounding effected area. The remedial works become challenging while the original structure should be hacked to inspect, repair or replace the affected element.

The element supposedly shall be easy to access, reach and inspect for any future treatment or maintenance. It is because to avoid the spread of malignancy to the other element especially to the building structure.

\subsection{Insufficient Length Of Owning}

Owning is the extension of roof from the original form of the building. This owning functioned as to protect from the rain splashed to the opening. Insufficient length would address to the water absorption to the wall and may keep the dampness that stimulate the growth of algae.

The length of owning depends on the steepness of this element. The more steepness, the lesser length of the owning's design. It is also depends on the orientation of the building and placement of the owning to a building whereby the wind flow will influenced the rainfall directions. As a resulted, the design of owning shall be decided to avoid from rainwater splashed to the wall or opening.

\subsection{Insufficient Provision for Thermal Movement}

The building has absorbed the heat from direct sunlight. This heat is kept in wall and transferred directly to the internal of the building. The cavity wall design with the gap in between two layers of wall to create thermal insulation and reduce the heat or cold absorption in the internal building. However, this wall is widely used in four season regions.

In Asian countries, a single layer wall is used. The heat is transferable to the internal wall without any insulator to reduce the heat. Insufficient design of wall might increase the percentage of thermal movement and result to overheat external and internal of the wall. The impact of this situation leads to dependence of the mechanical ventilation and a high capacity of energy usage.

\subsection{Insufficient Structural Design}

Structure is the strongest element of the building. The function of the structure is clearly to support the whole building elements and systems. Nevertheless, insufficient structural design such as the less size of the foundation, number of columns, location of the structure, the size of the reinforcement bar and mixture of the concrete shall bring the biggest problem to a building [11]. The element started to cracks and this live cracks developed until it shows some failure to location of the structural weakest point. With insufficient structural design, this building is unsafe to operate anymore.

\subsection{Ignore Maintenance Access When Designing}

Most of the architects working with art and their imagination through the design. Some of the architects are too concerned with accumulating design of the building scheme till obliviously the maintenance aspects in design stage. This weakness result to the difficulties in the maintenance operational works and ignorance of maintenance access.

These maintenance access is important to ensure that the building shall be accessed for inspect the condition of the building, to reduce the risk and cost in maintenance. The complications maintenance access shall increase the maintenance cost when the management has to rent a special machinery, tools and equipment to reach the affected area. Otherwise, the damage of the building will be left and fall inti oblivion.

\subsection{Less Consideration the Availability Of Maintenance Tool During Designing A Building}

The consideration of maintenance tools availability for cleaning work should be accounted during design stage. This is because to avoid from the increment of maintenance financial and budgetary in maintenance operational work. The special and custom design of maintenance tools and equipment should be considered 
for uncertainty in maintenance work. It will increase the maintenance running cost because the expertise of the tools is needed to operate the equipment. Therefore, this issues shall be well-thought-out during design stage.

\subsection{Not Relating Exterior Construction Material Selection to Weather and Climatic Condition}

Exterior material selection is important during design stage to reduce the climatic impact to the material. This material exposed to the climate with humidity, rain, acidic reaction, weathering and rapid obsolescence. The weak material will undergo a decay and obsolescence is a short period because this material is not being tested in weathering impact [24]. The material selection shall be decided and has the value on climatic tested to avoid external building decay.

\section{Methodology}

The good design achievement in the planning of buildings as worthy objects is understood and recognized, but less understood and appreciated is the need for maintenance. Therefore, these are the impact on maintenance management [17]:

a) Lack of fund due to major defects

b) Maintenance budget is increased

c) Difficulty in maintenance policy and planning implementation

d) Difficulty in repairing work

e) Maintenance frequency will increase

f) Maintenance works and cases will increase

g) Increase in maintenance time and duration

h) Lower maintenance quality

i) Hiring more expertise and professional person

The methodology procedure was produced to ensure that information obtain for this study was rigorously accomplish, relevant and capable of qualitative evaluation. Archives data on maintenance records is obtained from the Facilities Management Office UiTM and Politeknik Ungku Omar and Universiti Perguruan Sultan Idris. The three case studies is collected based on the similarity criteria aligned that is the three institutions is the government higher education institution, management of design decision, management board in design stage and maintenance management.

The respondents that involved in this research are from Maintenance Management Team and related Architect from these three case studies. The data collection is through the inspection on the building condition to survey, building defect cases present in the building and identify the major defect occurs especially on wall. All data will be analyzed by two (2) methods there are Frequency Analysis using SPSS software and Average Index Analysis. Frequency analysis is used to analyze the description of opened ended questions. This analysis presented in the frequency and percentage mode. In the other hand, the average index method is used to analysis like scale questions.

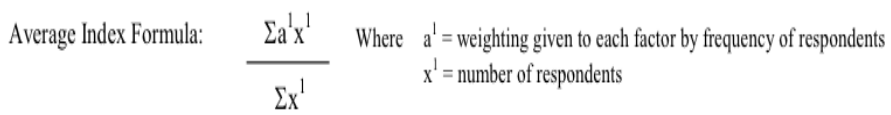

Selection of Student Centre at Universiti Teknologi Mara Perak, Student Centre at Politeknik Ungku Omar and Student Centre at Universiti Perguruan Sultan Idris as the case studies that all three of the building serves as an office building. There were five (5) categories of skill rating which represent the feedback of the respondents and the implication rating scale of Average Index in questionnaire for instance would be:

\begin{tabular}{|c|c|c|c|}
\hline Rating Scale & Average Index (a) & \multicolumn{2}{|c|}{ Categories } \\
\hline 1 & $1.00 \leq \mathrm{a} \leq 1.50$ & Ignorable & Doed not affect \\
\hline 2 & $1.50 \leq \mathrm{a} \leq 2.50$ & Not Important & Slightly affected \\
\hline 3 & $2.50 \leq \mathrm{a} \leq 3.50$ & Moderate & Moderately affected \\
\hline 4 & $3.50 \leq \mathrm{a} \leq 4.50$ & Important & Strongly affected \\
\hline 5 & $4.50 \leq \mathrm{a} \leq 5.00$ & Very Important & Exremely affected \\
\hline
\end{tabular}

Figure 3.1: A table shows scale of survey.

There are $6 \%$ of female respondents in this survey from the Facilities Unit of UiTM and the rest were males representing $94.4 \%$ of the total percentage. They are among the professional who is a support group for each department. Respondents consisted of three (3) Architects who represent $17 \%$, two (2) Engineer representing 11\%, nine (9) Building Technician who represent $50 \%$ and lastly only $22 \%$ is Development Officer and his assistance. Each of case study representing six six (6) respondents and overall respondents for these three (3) case study is eighteen (18). Studies were also conducted to identify the respondents experience in their respective fields. The study found a total of $61 \%$ of the respondents have experience of 5-10 years in the employment of a total of eleven (11) persons. Meanwhile, two (2) representing $11 \%$ of respondents have experience of 10 15 years from UiTM Engineer and Architect of the Universiti Perguruan Sultan Idris. The remaining five (5) have experience of 1-5 years involved in representing of $28 \%$. Pie chart below shows the analysis of respondent background.

\section{Gender}

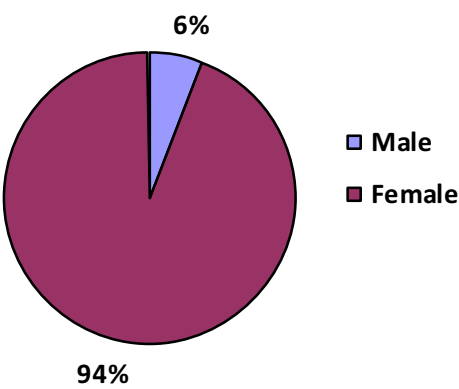

Respondent Occupation 


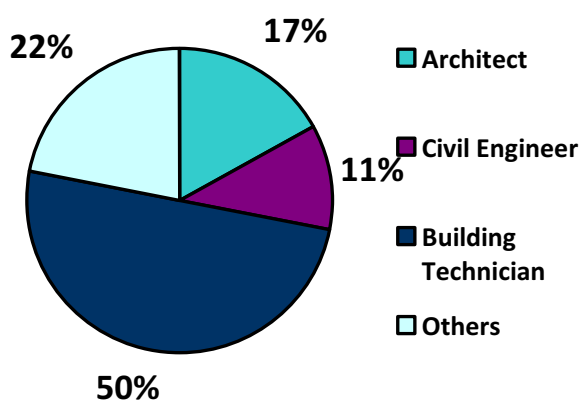

\section{Respondent Experience}

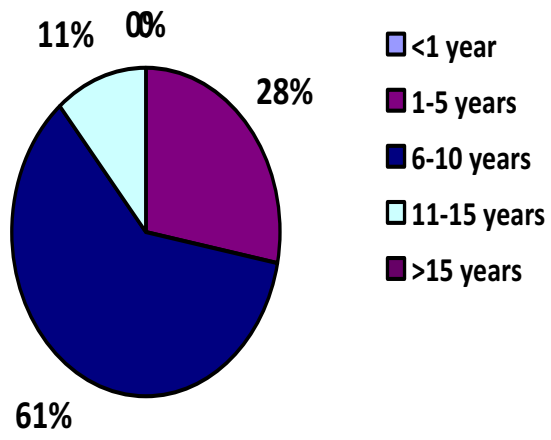

\section{Major Causes in Faulty Design}

This study is to evaluate the faulty design as main factors affected building maintenance, it is important to access the criteria of faulty design. By referring Table 4.1, six (6) most common causes of design failure, it has been tested in these different case studies [18]:

\section{Common Causes in Design Failures}

\begin{tabular}{|c|l|c|c|c|}
\hline No. & \multicolumn{1}{|c|}{ CAUSES } & UITM & PUO & UPSI \\
\hline 1. & $\begin{array}{l}\text { Failure to follow well } \\
\text { established design } \\
\text { criteria. }\end{array}$ & & & \\
\hline 2. & $\begin{array}{l}\text { Ignorance of the basic } \\
\text { physical properties of } \\
\text { materials. }\end{array}$ & $\sqrt{ }$ & $\sqrt{ }$ & $\sqrt{ }$ \\
\hline 3. & $\begin{array}{l}\text { Poor communication } \\
\text { between team. }\end{array}$ & $\sqrt{ }$ & & \\
\hline 4. & $\begin{array}{l}\text { Misjudgement of user } \\
\text { and climatic condition. }\end{array}$ & & $\sqrt{ }$ & \\
\hline 5. & Complex details. & $\sqrt{ }$ & \\
\hline 6. & $\begin{array}{l}\text { New innovation / } \\
\text { material that has not } \\
\text { been properly tested in } \\
\text { use }\end{array}$ & & & \\
\hline
\end{tabular}

Table 4.1: The most common causes design failures in Higher Education Institution offices.

All sources above was accessed and used as a guide for answers to interviews on all three Architects concerned.
Based on investigation carried out, most of them agreed that these six factors above is the cause of design fault in building but the main causes of design fault is poor communication between member or team. The communication between members is very importance to produce an effective and successful project. Due to the lack of two ways communications, interpretation of design can't be implemented smoothly. From analysis, most Architects agreed whereas the design fault, workmanship and materials is the main subject of presence building defects. Table 4.2 below present effect of design defect towards maintenance and 5.1 shows the variable of design defect affecting maintenance.

Table 4.1 shows the variable of design defect affected maintenance management based on inspection and survey on the selected case study. With average 4.9 and extremely affected on maintenance is poor detailing and jointing and with average 4.6 insufficient thickness of concrete cover that will make the building facade peel off and defect occur. According to A-Shiha (1993) Inadequate concrete cover will make corrosions reach the concrete reinforcement faster if the concrete cover on the steel bars is insufficient, which will result in corrosion of the steel bars and cracking of the concrete element. Another variable that strongly affected on maintenance are insufficient jointing between finishes faces, incorrect locating conduits and piping at critical structure locations, insufficient length of owning, insufficient provision for thermal movement, insufficient structural design, ignoring maintenance access when designing and lastly not concerned on aggressive environment and weather condition effect is strongly affect to maintenance and its range of average index about 3.5 to 4.2.

\section{Design Failure Affecting Maintenance}

\begin{tabular}{|c|c|c|c|}
\hline Variable & Mean & Rating Scale & Rank \\
\hline Poor detailing and jointing & 4.9 & $\begin{array}{c}\text { Extremely } \\
\text { affected }\end{array}$ & 1 \\
\hline Insufficient thickness of concrete cover & 4.6 & $\begin{array}{l}\text { Extremely } \\
\text { affected }\end{array}$ & 2 \\
\hline Insufficient jointing between finishes faces & 4.2 & $\begin{array}{l}\text { Strongly } \\
\text { affected }\end{array}$ & 3 \\
\hline $\begin{array}{l}\text { Incorrect locating conduits and piping at critical } \\
\text { structure locations }\end{array}$ & 4.1 & $\begin{array}{l}\text { Strongly } \\
\text { affected }\end{array}$ & 4 \\
\hline Insufficient lenght of owning & 4.1 & $\begin{array}{l}\text { Strongly } \\
\text { affected }\end{array}$ & 5 \\
\hline Insufficient provision for thermal movement & 3.9 & $\begin{array}{l}\text { Strongly } \\
\text { affected }\end{array}$ & 6 \\
\hline Insufficient structural design & 3.9 & $\begin{array}{l}\text { Strongly } \\
\text { affected }\end{array}$ & 7 \\
\hline Ignore maintenance access when designing & 3.7 & $\begin{array}{l}\text { Strongly } \\
\text { affected }\end{array}$ & 8 \\
\hline $\begin{array}{l}\text { Not concerned on aggressive environment and weather } \\
\text { condition effect }\end{array}$ & 3.5 & $\begin{array}{l}\text { Strongly } \\
\text { affected }\end{array}$ & 9 \\
\hline $\begin{array}{l}\text { Less consideration the availability of maintenance tool } \\
\text { during designing a building }\end{array}$ & 3.2 & $\begin{array}{l}\text { Moderately } \\
\text { affected }\end{array}$ & 10 \\
\hline Exceed the permissible deflection & 2.9 & $\begin{array}{l}\text { Moderately } \\
\text { affected }\end{array}$ & 11 \\
\hline $\begin{array}{l}\text { Not relating exterior construction material selection to } \\
\text { weather and climatic condition }\end{array}$ & 2.8 & $\begin{array}{l}\text { Moderately } \\
\text { affected }\end{array}$ & 12 \\
\hline
\end{tabular}


Table 4.2: Shows the Design Failure criteria in building.

This can be concluded that a designer should provide adequate structural design, proper access to maintenance equipment, proper exterior finishes compatible with climate conditions and sufficient detail in construction drawings in Table 4.3 [19].

The Impact Of Building Design Failure On Maintenance Management

\begin{tabular}{|c|c|c|c|}
\hline Variable & Mean & Rating Scale & Rank \\
\hline Lack of fund due to major defects & 4.5 & $\begin{array}{c}\text { Extremely } \\
\text { affected }\end{array}$ & 1 \\
\hline Maintenance budget will increase & 4.2 & $\begin{array}{l}\text { Strongly } \\
\text { affected }\end{array}$ & 2 \\
\hline Difficulty in maintenance policy and planning & 4 & $\begin{array}{l}\text { Strongly } \\
\text { affected }\end{array}$ & 3 \\
\hline Difficulty in repairing & 3.9 & $\begin{array}{l}\text { Strongly } \\
\text { affected }\end{array}$ & 4 \\
\hline Maintenance frequency will increase & 3.8 & $\begin{array}{l}\text { Strongly } \\
\text { affected }\end{array}$ & 5 \\
\hline Maintenance works will increase & 3.7 & $\begin{array}{l}\text { Strongly } \\
\text { affected }\end{array}$ & 6 \\
\hline Increase in maintenance time/duration & 3.6 & $\begin{array}{l}\text { Strongly } \\
\text { affected }\end{array}$ & 7 \\
\hline Lower maintenance quality & 3.3 & $\begin{array}{c}\text { Moderately } \\
\text { affected }\end{array}$ & 8 \\
\hline
\end{tabular}

Table 4.3: Shows the impact of building defect on maintenance management on Higher Education Institutions.

By using Average Index Formular by Likert Scale, eight (8) questions was evaluated the effect of design defect towards maintenance management. Maintenance persons agreed that building defects extremely affect to lack of fund due to major defects to maintenance management. According to Malaysian Department of Education mentioned that problem in maintenance is to getting maintenance funding, where it is too difficult and take a long time to approve it. Design defect also strongly affected on maintenance budget, effect on maintenance policy and planning, increasing in maintenance frequency and works and also affect to increasing in maintenance time and duration. Some of moderately affected on maintenance is on maintenance quality and less expertise and professional person in conducting the repairing work.

\section{Discussions}

The data obtain from the questionnaires analyzed by determined the main factors that contributed to the building defects on refurbished building. After do some research and after done observation on the selected case study, it is clearly shows that faulty design is the main factors or causes in the presence of building defects. This statement is supported by respondent and others past research done by many researchers. Researcher found that, the main effects is inadequate of funding due to major defects. A building with numerous design defects will increase budget of maintenance. The respondent also strongly believe that design defect strongly affected on maintenance budget, effect on maintenance policy and planning, increasing in maintenance frequency and works and also affect to increasing in maintenance time and duration. Some of them state that design defect moderately affect the maintenance quality and due to inadequate expertise and professional person. Design defect such poor detailing, jointing and insufficient thickness of concrete cover [23] is extremely affect the maintenance. Based on analysis conducted, researcher found that most of management prefers to use a preventive maintenance rather than others approach. They also mentioned that they prefer to hire an outsourced contractor due to several benefits such as expertise and specialized, strong fund, fast performance and their company culture and value. The management should take into account this matter in order to reduce maintenance cost and prolong their building life.

\section{References}

[1] Chong, W. and Low, S. (2006). "Latent Building Defects: Causes and Design Strategies to Prevent Them." J. Perform. Constr. Facil., 10.1061/(ASCE)08873828(2006)20:3(213), 213-221.

[2] Al-Hammad, A., Assaf, S. and Al-Shihah, M. (1997). 'The effect of faulty design on building maintenance'. Journal of Quality in Maintenance Engineering, 3(1), 29-39. | Article |

[3] David, M.N (2014), Exploring The Architecture of Everyday Life. United State of America, SAGE.

[4] Andre K.S.J and Albert H.C.T (2013). Maintenance, Replacement and Reliability: Theory and Application, Second Edition. United State of America, CRC Press. [5] Ramly, A. (2006). 'A link between design and maintenance', Journal of Building Engineers, 81(5), May. [6] Nicastro, D.H. (1997). Failure Mechanisms in Building Construction, ASCE Press, Reston, VA.

[7] Ishak, N.H., Chohan, A.H._and Ramly, A. (2007). Implications of Design Deficiency On Building Maintenance At Post-Occupational Stage. Journal of Building Appraisal (2007) 3, 115-124. doi:10.1057/palgrave.jba.2950061.

[8] Abdul Rahman, S. (2012), A Study On The Impact Of Design Defects Towards Building Maintenance Management, Unpublished degree dissertation, Universiti Teknologi MARA, Malaysia. '

[9] Douglas, J., and Ransom, W. H., 2007. Understanding Building Failures, 3rd edn. New York: Routledge. 326 pp.

[10] Seelay, Ivor H. (1987). Building Maintenance, Palgrave Macmillan, 2Rev Ed Edition.

[11] Hinks, J. and Cook, G. (2005). The Technology of Building Defects. New York: Taylor \& Francis.

[12] Watt, David S. (2007). Building Pathology: Priciples and Practice. Oxford, Blackwell Publishing.

[13] Ransom, W.H. (1981). Building Failures Diagnosis and Avoidance, $\mathbf{2}^{\text {nd }}$ Edition. London, E\&FN Spon.

[14] Low, S.P. and Darren, W. (2001). "Improving maintenance and reducing building defects through ISO 9000", Journal of Quality in Maintenance Engineering, Vol. 7 Iss: 1, pp.6-24.

[15] Assaf, S., Al-Hammad, A., and Al-Shihah, M. (1996). "Effects of Faulty Design and Construction on Building Maintenance." J. Perform. Constr. Facil., 
10.1061/(ASCE)0887-3828(1996)10:4(171), 171-174.

[16] Ryan, Christopher M.; Morrow, Lisa A. (1992). "Dysfunctional buildings or dysfunctional people: An examination of the sick building syndrome and allied disorders". Journal of Consulting and Clinical Psychology, Vol 60(2), Apr 1992, 220-224.

[17] Reekie, R.F. (1972). Design in The Built Environment. The University of Wisconsin: Madison, Crane, Russak.

[18] Lee. R. (1976), "Building Maintenance Management", The Chartered Institute of Building, Ascot, England.

[19] Assaf, et. al. (1996). Effects of Faulty Design and Construction on Building Maintenance. Journal of Performance of Constructed Facilities.

[20] Luigi T.De Luca, Propulsion physics (EDP Sciences, Les Ulis, 2009)

[21] F. De Lillo, F. Cecconi, G. Lacorata, A. Vulpiani, EPL, 84 (2008).

[22] http://wwwmainroads.wa.gov.au

[23] http://enggpedia.com

[24] Barry, A. R., (2005), Defects And Deterioration In Building, $2^{\text {nd }}$ Edition, Spon Press, New York. 